\title{
Pattern of Bacterial Pathogens Causing Urinary Tract Infection and Their Antibiotic Sensitivity: A Tertiary Care Hospital Experience
}

\author{
RAHMAN MR ${ }^{\mathrm{a}}$, RAHIM MA ${ }^{\mathrm{b}}$, AFROZE SR ${ }^{\mathrm{c}}$, AFROZ $^{\mathrm{c}}$, HAQUE HF $^{\mathrm{c}}$, MITRA P $^{\mathrm{d}}$, ANANNAMA ${ }^{\mathrm{b}}$, SAMAD \\ $\mathrm{T}^{\mathrm{e}}$, TAREQE $\mathrm{A}^{\mathrm{f}}$, AHMED JU' ${ }^{\mathrm{g}}$, AHMED AKMS $^{\mathrm{a}}$, HOSSAIN MD $^{\mathrm{a}}$, MUSAAKM ${ }^{\mathrm{h}}$, UDDIN KN ${ }^{\mathrm{h}}$
}

\begin{abstract}
Background and Aims: Urinary tract infection (UTI) is a common illness. The spectrum of bacteria causing UTI and their antibiotic sensitivity is not uniform. This study was designed to describe the bacteriological spectrum causing UTI and their antibiotic sensitivity.
\end{abstract}

Methods: This cross-sectional study was done in the Department of Internal Medicine, BIRDEM General Hospital from January to June, 2013.

Results: Total number of patients was 103 with females predominance (F:M ratio 2:1). Mean age was 57.5 years. Most (91.3\%) of the study population were diabetic with poor glycaemic control (mean HbA1c 9.9\%). Common symptoms were fever, dysuria, increased urinary frequency,

Introduction

Urinary tract infection (UTI) is defined as growth of micro-organisms $>10^{5} \mathrm{cfu} / \mathrm{ml}$ in mid-stream urine samples. UTI is the second most common infection through-out the world and it is estimated that worldwide

a. Md. Raziur Rahman, MD (Medicine), AKM Shaheen Ahmed, FCPS (Medicine), Md. Delwar Hossain, MD (Chest), Associate Professor, Internal Medicine, BIRDEM.

b. Muhammad Abdur Rahim, FCPS (Medicine), Mehruba Alam Ananna, FCPS (Medicine), Assistant Professor, Nephrology, BIRDEM.

c. Samira Rahat Afroze, FCPS (Medicine), Farhana Afroz, FCPS (Medicine), Hasna Fahmima Haque, FCPS (Medicine), Registrar, Internal Medicine, BIRDEM.

d. Palash Mitra, Assistant Registrar, Nephrology and Dialysis Unit, BIRDEM.

e. Tabassum Samad, FCPS (Medicine), Registrar, Nephrology, BIRDEM.

f. Ashfaqe Tareqe, MBBS, Assistant Registrar, Internal Medicine, BIRDEM.

g. Jamal Uddin Ahmed, FCPS (Medicine), Assistant Professor, Internal Medicine, BIRDEM.

h. AKM Musa, FCPS (Medicine), Khwaja Nazim Uddin, FCPS (Medicine), Professor, Internal Medicine, BIRDEM.

Address of Correspondence: Dr. Md. Raziur Rahman, MD (Medicine), Associate Professor, Internal Medicine, BIRDEM. E-mail:raziur@hotmail.com,muradrahim23@yahoo.com.

Received: 10 January 2014,

Accepted: 22 December 2014 suprapubic pain, vomiting and loin pain. Neutrophilic leukocytosis was common (94.2\%). E. coli (79.6\%) was the commonest aetiological agent followed by Klebsiella (9.7\%), Citrobacter (3.9\%), Acinetobacter (1.9\%), Enterobacter (1.9\%), Enterococcus (1.9\%) and Pseudomonas (0.9\%). Imipenem (100\%), aminoglycosides e.g. amikacin and gentamycin and nitrofurantoin were among the most sensitive antibiotics.

Conclusion: E. coli is the commonest organism causing UTI and imipenem, amikacin and nitrofurantoin are the most sensitive antibiotics.

Key words: antibiotics, resistance, sensitivity, urinary tract infection.

(Birdem Med J 2015; 5(1): 20-23)

150 million cases of UTI occur per year. ${ }^{1,2}$ It is common in community and in hospital settings. ${ }^{3-5}$ Escherichia coli (E. coli) is the commonest pathogen through-out the world. ${ }^{3-8}$ Antibiotics are the cornerstone in treating UTI. Bacterial sensitivity to anti-bacterial agents varies in different places and in same place from time to time. Easy availability and non-judicious use of anti-microbial agents have led to increased resistance of common pathogens against commonly used antibiotics. Thus empirical choice of antibiotics in community acquired UTI is not uniform and probably not justified as well. Choice of antibiotic depends on local guidelines, if available. This study was designed to describe the pattern of micro-organisms causing UTI and their antibiotic sensitivity among hospitalized adult patients.

\section{Materials and methods}

This hospital-based cross-sectional study was done in the Department of Internal Medicine, Bangladesh Institute of Research and Rehabilitation in Diabetes, Endocrine and Metabolic Disorders (BIRDEM), Shahbag, Dhaka, Bangladesh from January to June, 2013. 


\section{Patients}

Hospitalized adult patients with symptoms and clinical diagnosis of UTI were primarily enrolled for study. Those with significant growth of micro-organisms $\left(>10^{5} \mathrm{cfu} /\right.$ $\mathrm{ml}$ ) from urine cultures were finally included for analysis. Patients with no/insignificant growth of pathogens or growth of candida, catheterized patients and pregnant patients were excluded from the study.

\section{Microbiological testing}

Standard clean-catch technique was applied for collection of mid-stream urine. Urine samples were sent to microbiology laboratory in one hour, where it was inoculated in McConkey's and blood agar media within two hours. Those with growth of micro-organisms were further tested for antibiotic sensitivity using standard disc-diffusion methods.

\section{Data collection and statistical analysis}

Data were collected in pre-designed pre-tested case record forms. After collecting data, they were checked and entered in to computer. Data were analyzed by using SPSS version 12.0. Results were presented in tables.

\section{Results}

Total number of patients was 103, male were 34, female 69 (M:F ratio 1:2). Mean age was 57.5 \pm 9.5 (range 19-80) years. Base-line characteristics of the study population are presented in table I. Most (94, 91.3\%) of the study population were diabetic. Other common co-morbidities are presented in table II. Fever (93.2\%) was the commonest symptom and other features are presented in table III. Eighteen (17.5\%) patients had past history of UTI including recurrent UTI in 3 (2.9\%) cases. Neutrophilic leukocytosis was common (94.2\%). Almost all (86/94, 91.5\%) diabetic patients had poor glycaemic control (HbA1c > 7\%). Cystitis was common (63.1\%), followed by pyelonephritis (33\%). Bilateral pyelonephritis was present in $3(2.9 \%)$ cases and emphysematous pyelonephritis in 1 case. E. coli (82, $79.6 \%$ ) was the commonest aetiological agent followed by Klebsiella (10, 9.7\%), Citrobacter (4,3.9\%), Acinetobacter (2, 1.9\%), Enterobacter (2, 1.9\%), Enterococcus (2, 1.9\%) and Pseudomonas (1, 0.9\%). Over half (44/82, 53.7\%) of E. coli and Klebsiella (6/10, $60 \%$ ) were found positive for extended spectrum beta lactamase (ESBL) enzyme. Three $(2.9 \%)$ cases were complicated by septicaemia and 11 (10.7\%) cases by acute kidney injury (AKI). Imipenem, amikacin, gentamycin and nitrofurantoin were among the most common sensitive antibiotics, whereas cefixim, cefuroxime, ciprofloxacin and co-trimoxazole were mostly resistant (table IV \& V).

Table-I

Base-line characteristics of the study population $(N=103)$

\begin{tabular}{lc} 
Mean age (years) & $57.5 \pm 9.5$ \\
Male:female & $1: 2$ \\
DM: non-DM & $10.4: 1$ \\
Mean duration of DM (years) & $11.2 \pm 5.7$ \\
Mean HbA1c (\%) & $9.9 \pm 3.4$ \\
Mean RBS at admission (m.mol/L) & $13.7 \pm 4.6$ \\
\hline
\end{tabular}

RBS $=$ random blood sugar

Table-II

Co-morbidities among the study subjects $(N=103)$

\begin{tabular}{lcc} 
Co-morbidity & Frequency & Percentage \\
\hline DM & 94 & 91.3 \\
Hypertension & 58 & 56.3 \\
IHD & 16 & 15.5 \\
CKD & 34 & 33 \\
Stroke & 5 & 4.9 \\
Dyslipidaemia & 31 & 30.1 \\
Fatty liver & 22 & 21.4 \\
\hline
\end{tabular}

$\mathrm{DM}$ = diabetes mellitus; IHD = ischaemic heart disease; CKD $=$ chronic kidney disease

Table-III

Presenting features of the study subjects $(N=103)$

\begin{tabular}{lcc} 
Presenting features & Frequency & Percentage \\
\hline Fever & 96 & 93.2 \\
Increased urinary frequency & 48 & 46.6 \\
Dysuria & 82 & 79.6 \\
Loin pain & 31 & 30.1 \\
Supra-pubic pain & 47 & 45.6 \\
Incontinence & 8 & 7.8 \\
Vomiting & 42 & 40.8 \\
\hline
\end{tabular}

All patients had more than one symptom 
Table IV

\begin{tabular}{|c|c|c|c|c|c|c|c|c|}
\hline \multirow{3}{*}{$\begin{array}{l}\text { Bacterial organism } \\
\text { Antibiotic } \\
\end{array}$} & \multicolumn{8}{|c|}{ Antibiotic sensitivity and resistance patterns of E. coli and Klebsiella sp. } \\
\hline & \multicolumn{2}{|c|}{$\begin{array}{l}\text { E. Coli } \\
\text { N (\%) }\end{array}$} & \multicolumn{2}{|c|}{$\begin{array}{c}\text { E. Coli (ESBL) } \\
\text { N (\%) }\end{array}$} & \multicolumn{2}{|c|}{$\begin{array}{l}\text { Klebsiella } \\
\text { N (\%) }\end{array}$} & \multicolumn{2}{|c|}{$\begin{array}{c}\text { Klebsiella (ESBL) } \\
\text { N (\%) }\end{array}$} \\
\hline & sen & res & sen & res & sen & res & sen & res \\
\hline Amikacin & $38(100)$ & $0(0)$ & $43(99.2)$ & $1(0.8)$ & $2(50)$ & $2(50)$ & $6(100)$ & $0(0.0)$ \\
\hline Augmantin & $0(0)$ & $38(100)$ & $0(0)$ & $44(100)$ & $0(0)$ & $4(100)$ & $0(0)$ & $6(100)$ \\
\hline Cefixime & $10(26.3)$ & 28 (73.7) & $0(0)$ & $44(100)$ & $2(50)$ & $2(50)$ & $0(0)$ & $6(100)$ \\
\hline Ceftazidime & $10(26.3)$ & 28 (73.7) & $0(0)$ & $44(100)$ & $2(50)$ & $2(50)$ & $0(0)$ & $4(100)$ \\
\hline Ceftriaxone & $10(26.3)$ & 28 (73.7) & $0(0)$ & $44(100)$ & $2(50)$ & $2(50)$ & $0(0)$ & $4(100)$ \\
\hline Cefuroxime & $10(26.3)$ & $28(73.7)$ & $0(0)$ & $44(100)$ & $2(50)$ & $2(50)$ & $0(0)$ & $4(100)$ \\
\hline Ciprofloxacin & $12(31.6)$ & 26 (68.4) & $0(0)$ & $44(100)$ & $2(50)$ & $2(50)$ & $0(0)$ & $6(100)$ \\
\hline Colistin & - & - & - & - & $2(100)$ & $0(0)$ & - & - \\
\hline Co-trimox & 12 (31.6) & $26(68.4)$ & $20(45.5)$ & $24(54.5)$ & $2(50)$ & $2(50)$ & $0(0)$ & $6(100)$ \\
\hline Gentamicin & $24(63.2)$ & 14 (36.8) & $20(45.5)$ & $24(54.5)$ & $2(50)$ & $2(50)$ & $4(100)$ & $0(0)$ \\
\hline Imipenem & $38(100)$ & $0(0)$ & $44(100)$ & $0(0)$ & $4(100)$ & $0(0)$ & $6(100)$ & $0(0)$ \\
\hline Mecillinam & $24(63.2)$ & 14 (36.8) & $16(36.4)$ & $28(63.6)$ & $2(50)$ & $2(50)$ & $6(100)$ & $0(0)$ \\
\hline Netilmicin & 38 (100) & $0(0)$ & 40 (90.9) & $4(9.1)$ & $4(100)$ & $0(0)$ & $4(100)$ & $0(0)$ \\
\hline Nitrofurantoin & 36 (94.3) & $2(5.7)$ & 42 (95.5) & $2(4.5)$ & $4(100)$ & $0(0)$ & $0(0)$ & $4(100)$ \\
\hline Vancomycin & - & - & - & - & - & - & - & - \\
\hline Piperacilin & - & - & - & - & - & - & - & - \\
\hline PPC+Tazobac & - & - & - & - & $0(0)$ & $2(100)$ & - & - \\
\hline
\end{tabular}

*Not all specimens were tested against all antibiotics listed; sen=sensitive; res=resistant; PPC=piperacilin.

Table-V

Antibiotic sensitivity and resistance patterns of less common bacterial isolates

\begin{tabular}{|c|c|c|c|c|c|c|c|c|c|c|}
\hline $\begin{array}{l}\text { Bacterial } \\
\text { organism }\end{array}$ & $\begin{array}{l}\text { Acine- } \\
\text { tobac }\end{array}$ & $(\mathrm{N}=2)$ & $\begin{array}{l}\text { Citro- } \\
\text { bacter }\end{array}$ & $(\mathrm{N}=4)$ & $\begin{array}{l}\text { Entero- } \\
\text { bacter }\end{array}$ & $\begin{array}{c}(\mathrm{N}=2) \\
(\mathrm{ESBL})\end{array}$ & $\begin{array}{l}\text { Entero- } \\
\text { coccus }\end{array}$ & $(\mathrm{N}=2)$ & $\begin{array}{l}\text { Pseudo- } \\
\text { monas }\end{array}$ & $(\mathrm{N}=1)$ \\
\hline Antibiotic & sen & res & sen & res & sen & res & sen & res & sen & res \\
\hline Amikacin & 0 & 2 & 2 & 2 & 0 & 2 & 2 & 0 & 1 & 0 \\
\hline Augmantin & 0 & 2 & 0 & 4 & 0 & 2 & 0 & 2 & 0 & 1 \\
\hline Cefixime & 0 & 2 & 2 & 2 & 0 & 2 & - & - & 1 & 0 \\
\hline Ceftazidime & - & - & 2 & 2 & 0 & 2 & - & - & 1 & 0 \\
\hline Ceftriaxone & 0 & 2 & 2 & 2 & 0 & 2 & - & - & 0 & 1 \\
\hline Cefuroxime & - & - & 2 & 2 & 0 & 2 & - & - & 0 & 1 \\
\hline Ciprofloxacin & - & - & 2 & 2 & 0 & 2 & 2 & 0 & 0 & 1 \\
\hline Colistin & - & - & - & - & 2 & 0 & - & - & - & - \\
\hline Co-trimox & 0 & 2 & 2 & 2 & 0 & 2 & 0 & 2 & 1 & 0 \\
\hline Gentamicin & 0 & 2 & 2 & 2 & 0 & 2 & 2 & 0 & 0 & 1 \\
\hline Imipenem & 2 & 0 & 4 & 0 & 2 & 0 & - & - & 0 & 1 \\
\hline Mecillinam & - & - & 0 & 4 & 2 & 0 & - & - & 0 & 1 \\
\hline Netilmicin & 2 & 0 & 2 & 2 & 0 & 2 & 2 & 0 & 0 & 1 \\
\hline Nitrofurantoin & - & - & 0 & 4 & 0 & 2 & 2 & 0 & 0 & 1 \\
\hline Vancomycin & - & - & - & - & - & - & 2 & 0 & - & - \\
\hline Piperacilin & - & - & - & - & - & - & - & - & - & - \\
\hline PPC+Tazobac & - & - & - & - & 2 & 0 & - & - & - & - \\
\hline
\end{tabular}

*Not all specimens were tested against all antibiotics listed; sen=sensitive; res=resistant; PPC=piperacilin. 


\section{Discussion}

Antibiotics remain the mainstay for treating bacterial infections, but increasing and changing resistance pattern of bacteria against antibiotics are prime barrier against infection. In this study we have evaluated the pattern of bacterial pathogens causing UTI and their antibiotic sensitivity in our institute.

Mean age of the study population was over 50 years with females being double than the males. In four different reports from Dhaka, Bangladesh mean age was a bit lower, but females were common sufferers. ${ }^{3,9-11}$ Diabetes and hypertension were the two most common co-morbidities among our study population and control of blood glucose was poor among diabetics. Saber et all. in their study concluded that diabetes is a risk factor for UTI. ${ }^{4}$

E coli was the commonest organism causing UTI in this current study which was consistent with local as well as international reports..$^{3-9,11,12}$ Overall bacteriological spectrum was almost similar to other recent studies, but the antibiotic resistant pattern is somewhat different. Increasing resistance to common antimicrobials like cephalosporins, cotrimoxazole and quinolones are becoming evident, but amikacin, imipenem and nitrofurantoin remain sensitive to almost all types of organisms. Similar reports are published in recent literatures from Bangladesh. ${ }^{3,9}$ Thus empirical use of antibiotics for UTI is becoming difficult and unwise. Moreover, increasing number of ESBL positive organisms are being isolated as aetioloical agents for UTI as seen in our study and another two recent studies. ${ }^{9,10}$

This study had some limitations. Limited number of patients were evaluated over a short period of time. It was a hospital-based study and most patients were diabetic; whether similar bacteriology and antibiotic sensitivity pattern occurs in community, among nondiabetics and ambulatory patients are not clear.

From the current study it can be concluded that UTI occurs more commonly among diabetic females with poor glycaemic control. E coli and Klebsiella are the commonest organisms. Amikacin, imipenem and nitrofurantoins remain the most sensitive agents. Urine culture and sensitivity of micro-organisms should be done before prescribing antibiotics, wherever possible.

\section{Acknowledgement}

We express our acknowledgement to Dr. Lovely Barai, FCPS (Microbiology), Associate Professor, Department of Microbiology, BIRDEM General Hospital, for her support and advice in doing the research and preparation of the manuscript.

\section{References}

1. Amin M, Mehdinejad M, Pourdangchi Z. Study of bacteria isolated from urinary tract infections and determination of their susceptibility to antibiotics. Jundishapur J Microbiology 2009; 2(3): 118-23.

2. Karlowsky JA, Kelly LJ, Thornsberry C, Jones ME, Sahm D. Trends in antimicrobial resistance among urinary tract infection isolates of Escherichia coli from female outpatients in the United States. Antimicrob Agents Chemother 2002; 46: 2540-45.

3. Shilpi T, Ahmed MN, Huq SMA, Baul SK, Khatun M. Isolation of bacteria causing urinary tract infections and their antibiotic susceptibility profile at Anwar Khan Modern Medical College Hospital. AKMMC J 2013; 4(2): 23-27.

4. Saber MH, Barai L, Haq JA, Jilani MSA, Begum MJ. The pattern of organism causing urinary tract infection in diabetic and non-diabetic patients in Bangladesh. Bang $\mathrm{J}$ Med Microbiol 2010; 4(1): 6-8.

5. Irenge LM, Kabego L, Vandenberg O, Chirimwami RB, Gala J-L. Antimicrobial resistance in urinary isolates from inpatients and outpatients at a tertiary care hospital in South-Kivu Province (Democratic Republic of Congo). BMC Res Notes 2014; 7: 374.

6. Ahmed S. Pattern of urinary tract infection in Kashmir and antimicrobial susceptibility. Bangladesh Med Res Counc Bull 2012; 38(3): 79-83.

7. Parvin US, Hossain MA, Musa AK, Mahmud C, Islam MT, Haque $\mathrm{N}$ et al. Pattern of aerobic bacteria with antibacterial susceptibility causing community acquired urinary tract infection. Mymensingh Med J 2009; 18(2): 148-53.

8. Aswani SM, Chandrashekar UK, Shivashankara KN, Pruthvi BC. Clinical profile of urinary tract infections in diabetics and non-diabetics. Australas Med J 2014; 7(1): 29-34.

9. Biswas R, Rabbani R, Ahmed HS, Sarker MAA, Zafrin N, Rahman MM. Antibiotic sensitivity pattern of urinary tract infection at a tertiary care hospital. Bangladesh Crit Care J 2014; 2(1): 21-24.

10. Masud MR, Afroz H, Fakruddin M. Prevalence of extended-spectrum beta-lactamase positive bacteria in radiologically positive urinary tract infection. SpringerPlus 2014; 3: 216.

11. Shill MC, Huda NH, Moain FB, Karmakar UK. Prevalence of uropathogens in diabetic patients and their corresponding resistance patterns: results of a survey conducted at diagnostic centers in Dhaka, Bangladesh. Oman Med J 2010; 25(4): 282-85.

12. Hasan MK, Uddin KN, Ahmed AKMS, Sarker RSC, Haque M, Musa AKM. Differences in bacteriological and antibiotic sensitivity patterns in UTI among hospitalized diabetic and nondiabetic patients. J Medicine 2007; 8: 10-13. 